\title{
UPAYA MENINGKATKAN DISIPLIN GURU DALAM KEHADIRAN MENGAJAR DI KELAS MELALUI KETELADANAN OLEH KEPALA SEKOLAH DI SMP NEGERI 5 PENAJAM PASER UTARA TAHUN PELAJARAN 2017-2018
}

\author{
Prayitno \\ SMP Negeri 5 Penajam Paser Utara
}

\begin{abstract}
ABSTRAK
Penelitian ini bertujuan untuk mendeskripsikan proses meningkatkan disiplin guru dalam kehadiran mengajar di kelas melalui keteladanan oleh kepala sekolah . Penelitian dilakukan dengan dua siklus dan masing-masing siklus terdiri atas empat tahapan, yakni: perencanaan, pelaksanaan, observasi dan refleksi. Indikator keberhasilan yang ditetapkan adalah: bila minimal terdapat $85 \%$ guru tergolong sangat baik dan baik dalam aspek kehadiran mengajar di kelas, maka sudah dapat dikatakan tindakan yang diterapkan berhasil. Aspek yang diukur dalam menilai keberhasilan tindakan adalah kehadiran guru di sekolah pada Umumnya dan kehadiran Guru pada saat mengajar di kelas. Dari analisis diperoleh bahwa terjadi peningkatan kedisiplinan guru dalam kehadiran mengajar di kelas dari siklus I ke siklus II. Ketercapaian indikator kinerja terdapat pada tindakan ke II. Dengan demikian dapat disimpulkan bahwa melalui Keteladanan oleh Kepala sekolah dapat meningkatkan Kehadiran guru dalam mengajar di Kelas pada guru kelas 7,8 dan 9 di SMP Negeri 5 Penajam Paser Utara.
\end{abstract}

Kata kunci: Disiplin, Keteladanan

\section{PENDAHULUAN}

Usaha meningkatkan mutu pendidikan sesuai dengan cita-cita bangsa Indonesia, untuk mewujudkan kesejahteraan umum dan mencerdaskan kehidupan bangsa, di mana pendidikan mempunyai peranan penting dalam meningkatkan ketaqwaan kepada Tuhan Yang Maha Esa, kecerdasan, dan ketrampilan.

Untuk melaksanakan tugas dalam meningkatkan mutu pendidikan maka diadakan proses belajar mengajar, guru merupakan figur sentral, di tangan gurulah terletak kemungkinan berhasil atau tidaknya pencapaian tujuan belajar mengajar di sekolah. Oleh karena itu tugas dan peran guru bukan saja mendidik, mengajar dan melatih tetapi juga bagaimana guru dapat membaca situasi kelas dan kondisi siswanya dalam menerima pelajaran.

Untuk meningkatkan peranan guru dalam proses belajar mengajar dan hasil belajar siswa, maka guru diharapkan mampu menciptakan lingkungan belajar yang efektif dan akan mampu mengelola kelas. Guru adalah pendidik profesional dengan tugas utama mendidik dan mengevaluasi peserta didik, pada pendidikan anak usia dini jalur pendidikan formal, pendidikan dasar dan pendidikan menengah. Sementara pegawai dunia pendidikan merupakan bagian dari tenaga kependidikan, yaitu anggota masyarakat yang mengabdikan diri dan diangkat untuk menunjang penyelenggaraan pendidikan. Dalam informasi tentang wawasan Wiyatamandala, kedisiplinan guru 
diartikan sebagai sikap mental yang mengandung kerelaan mematuhi semua ketentuan, peraturan dan norma yang berlaku dalam menunaikan tugas dan tangung jawab.

Dari pengertian diatas dapat disimpulkan, kedisiplinan guru dan pegawai adalah sikap penuh kerelaan dalam mematuhi semua aturan dan norma yang ada dalam menjalankan tugasnya sebagai bentuk tanggung jawabnya terhadap pendidikan anak didiknya. Karena bagaimana pun seorang guru atau tenaga kependidikan (pegawai), merupakan cermin bagi anak didiknya dalam sikap atau teladan, dan sikap disiplin guru dan tenaga kependidikan (pegawai) akan memberikan warna terhadap hasil pendidikan yang jauh lebih baik.

Keberhasilan proses pembelajaran sangat bergantung pada beberapa faktor diantaranya adalah faktor guru. Guru sangat memegang peranan penting dalam keberhasilan proses pembelajaran. Guru yang mempunyai kompetensi yang baik tentunya akan sangat mendukung keberhasilan proses pembelajaran.

Peranan guru selain sebagai seorang pengajar, guru juga berperan sebagai seorang pendidik. Pendidik adalah seiap orang yang dengan sengaja mempengaruhi orang lain untuk mencapai tingkat kemanusiaan yang lebih tinggi (Sutari Imam Barnado, 1989:44). Sehinggga sebagai pendidik, seorang guru harus memiliki kesadaran atau merasa mempunyai tugas dan kewajiban untuk mendidik. Tugas mendidik adalah tugas yang amat mulia atas dasar "panggilan" yang teramat suci. Sebagai komponen sentral dalam system pendidikan, pendidik mempunyai peran utama dalam membangun fondamen-fondamen hari depan corak kemanusiaan. Corak kemanusiaan yang dibangun dalam rangka pembangunan nasional kita adalah "manusia Indonesia seutuhnya", yaitu manusia yang beriman dan bertaqwa kepada Tuhan Yang Maha Esa, percaya diri, disiplin, bermoral dan bertanggung jawab. Untuk mewujudkan hal itu, keteladanan dari seorang guru sebagai pendidik sangat dibutuhkan.

Keteladanan guru dapat dilihat dari prilaku guru sehari-hari baik didalam sekolah maupun diluar sekolah. Selain keteladanan guru, kedisiplinan guru juga menjadi salah satu hal penting yang harus dimiliki oleh guru sebagai seorang pengajar dan pendidik.

Fakta dilapangan yang sering kita jumpai disekolah adalah kurang disiplinnya guru, terutama masalah disiplin guru masuk kedalam kelas pada saat kegiatan pembelajaran dikelas.

Berdasarkan uraian diatas, penulis tertarik untuk melakukan penelitian tindakan sekolah dengan judul : "Upaya Meningkatkan Disiplin Guru dalam Kehadiran Mengajar Dikelas Melalui Keteladanan oleh Kepala Sekolah di SMP Negeri 5 Penajam Paser Utara"

Tujuan dari penelitian ini adalah ingin mencari alternatif pemecahan masalah sebagai upaya meningkatkan disiplin guru dalam kehadiran mengajar dikelas dan untuk menciptakan suasana kondusif melalui keteladanan oleh kepala sekolah.

Di masa lalu, kepala sekolah yang berperan sebagai manajer yang efektif telah dianggap cukup. Di masa itu, kebanyakan kepala sekolah diharapkan mentaati ketentuan dan kebijakan Dinas Pendidikan, mengatasi isu-isu ketenagaan, pengadaan fasilitas dan infrastruktur, menyesuaikan anggaran, memelihara agar gedung sekolah nyaman dan aman, memelihara hubungan dengan masyarakat, memastikan kantin sekolah dan UKS berjalan lancar. Semua ini masih tetap harus dilakukan oleh kepala sekolah. 
Akan tetapi, sekarang kepala sekolah harus melakukan hal yang lebih dari semua itu.

Berbagai penelitian menunjukkan peran kunci yang dapat dilakukan kepala sekolah agar dapat meningkatkan belajar dan pembelajaran, jelas bahwa kepala sekolah harus berperan sebagai leaders for learning (The Institute for Educational Leadership, 2000). Para kepala sekolah harus mengetahui isi pelajaran dan teknik-teknik pedagogis. Para kepala sekolah harus bekerja bersama guru untuk meningkatkan keterampilan. Kepala sekolah harus mengumpulkan, menganalisis, dan menggunakan data dengan cara-cara yang menumbuhkan keunggulan. Mereka harus berkumpul siswa, guru, orang tua, organisasi-organisasi layanan sosial dan kesehatan. Organisasi kepemudaan, dunia usaha, warga sekitar sekolah untuk meningkatkan kinerja siswa. Selanjutnya para kepala sekolah itu juga harus memiliki keterampilan dan pengetahuan kepemimpinan dalam rangka memanfaatkan kewenangannya untuk mencari strategi-strategi yang diperlukan.

Mereka seharusnya melakukan itu semua, akan tetapi sayang, sering dijumpai bahwa mereka tidak melakukannya. Meskipun masyarakat pada umumnya memberi sorotan kepada kepala sekolah ketika hasil Ujian Nasional siswa diumumkan dan mengajukan usul untuk memberi sanksi apabila sekolah tidak menunjukkan hasil sebagaimana diharapkan, para kepala sekolah di masa lalu tidak banyak melalukan persiapan atau melakukan pengembangan keprofesionalan berkelanjutan untuk membekali diri dalam rangka

melaksanakan peran baru tersebut. Pihak pemerintah daerah, atau dinas pendidikan, selama ini juga lebih banyak mendorong kepala sekolah untuk sekedar mentaati peraturan yang ada, berusaha untuk mengelola tuntutan menjalankan kepala sekolah yang berlipat ganda di era meningkatnya harapan, kebutuhan siswa yang kompleks, akuntabilitas yang terus meningkat, peningkatan keberagaman, dan sabagainya.

Tidak ada alternatif lain, masyarakat di seluruh negeri ini harus "reinvent the principalship" untuk memampukan para kepala sekolah dalam menghadapi tantangan abad 21, dan untuk menjamin para pemimpin bagi belajar siswa yang dibutuhkan untuk membimbing agar sekolah dan siswanya yang dipimpinnya mencapai keberhasilan.

Keberhasilan siswa dalam pembelajaran serta peningkatan mutu sekolah tidak hanya menjadi tanggung jawab kepala sekolah saja, akan tetapi menjadi tanggung jawab bersama antara, guru, orang tua atau masyarakat serta pemerintah.

Dalam bidang pendidikan, yang dimaksud dengan mutu memiliki pengertian sesuai dengan makna yang terkandung dalam siklus pembelajaran. Secara ringkas dapat disebutkan beberapa kata kunci pengertian mutu, yaitu: sesuai standar (fitness to standard), sesuai penggunaan pasar/pelanggan (fitness to use), sesuai perkembangan kebutuhan (fitness to latent requirements), dan sesuai lingkungan global (fitness to global environmental requirements). Adapun yang dimaksud mutu sesuai dengan standar, yaitu jika salah satu aspek dalam pengelolaan pendidikan itu sesuai dengan standar yang telah ditetapkan. Garvin seperti dikutip Gaspersz mendefinisikan delapan dimensi yang dapat digunakan untuk menganalisis karakteristik suatu mutu, yaitu: (1) kinerja (performance), (2) 
feature, (3) kehandalan (reliability), (4) konfirmasi (conformance),

durability, (6) kompetensi pelayanan (servitability), (7) estetika (aestetics), dan (8) kualitas yang dipersepsikan pelanggan yang bersifat subjektif. Dalam pandangan masyarakat umum sering dijumpai bahwa mutu sekolah atau keunggulan sekolah dapat dilihat dari ukuran fisik sekolah, seperti gedung dan jumlah ekstra kurikuler yang disediakan. Ada pula masyarakat yang berpendapat bahwa kualitas sekolah dapat dilihat dari jumlah lulusan sekolah tersebut yang diterima di jenjang pendidikan selanjutnya. Untuk dapat memahami kualitas pendidikan formal di sekolah, perlu kiranya melihat pendidikan formal di sekolah sebagai suatu sistem. Selanjutnya mutu sistem tergantung pada mutu komponen yang membentuk sistem, serta proses yang berlangsung hingga membuahkan hasil.

Kinerja guru meliputi kedisiplinan guru dan etos kerja. Apabila kedisiplinan telah menjadi budaya sekolah, maka arah pencapaian peningkatan mutu sekolah akan tercapai.

Budaya sekolah adalah nilai-nilai dominan yang didukung oleh sekolah atau falsafah yang menuntun kebijakan sekolah terhadap semua unsur dan komponen sekolah termasuk stakeholders pendidikan, seperti cara melaksanakan pekerjaan di sekolah serta asumsi atau kepercayaan dasar yang dianut oleh personil sekolah. Budaya sekolah merujuk pada suatu sistem nilai, kepercayaan dan normanorma yang diterima secara bersama, serta dilaksanakan dengan penuh kesadaran sebagai perilaku alami, yang dibentuk oleh lingkungan yang menciptakan pemahaman yang sama diantara seluruh unsur dan personil sekolah baik itu kepala sekolah, guru, staf, siswa dan jika perlu membentuk opini masyarakat yang sama dengan sekolah. (Akhmad Sudrajat, 2010).

Beberapa manfaat yang bisa diambil dari upaya pengembangan budaya sekolah, diantaranya : (1) menjamin kualitas kerja yang lebih baik; (2) membuka seluruh jaringan komunikasi dari segala jenis dan level baik komunikasi vertikal maupun horisontal; (3) lebih terbuka dan transparan; (4) menciptakan kebersamaan dan rasa saling memiliki yang tinggi; (4) meningkatkan solidaritas dan rasa kekeluargaan; (5) jika menemukan kesalahan akan segera dapat diperbaiki; dan (6) dapat beradaptasi dengan baik terhadap perkembangan IPTEK. Selain beberapa manfaat di atas, manfaat lain bagi individu (pribadi) dan kelompok adalah : (1) meningkatkan kepuasan kerja; (2) pergaulan lebih akrab; (3) disiplin meningkat; (4) pengawasan fungsional bisa lebih ringan; (5) muncul keinginan untuk selalu ingin berbuat proaktif; (6) belajar dan berprestasi terus serta; dan (7) selalu ingin memberikan yang terbaik bagi sekolah, keluarga, orang lain dan diri sendiri.

Penerapan budaya sekolah termasuk penerapan disiplin semua warga sekolah dapat terwujud apabila semua warga sekolah mempunyai komitmen yang kuat untuk mewujudkannya.

Kepala sekolah selaku pemimpin pembelajaran mempunyai peran yang sangat strategis dalam pencapaian tujuan sekolah dalam meningkatkan mutu. Salah satu faktor yang penting adalah adanya keteladanan (contoh) yang diberikan oleh kepala sekolah. Hal ini seperti falsafah pendidikan yang dikemukakan oleh Bapak Pendidikan Nasional Ki Hadjar Dewantara, "Ing Ngarso Sung Tuladha." 
Kepala sekolah selaku pemimpin pembelajaran harus bisa memberikan contoh kepada semua wara sekolah agar tercipta budaya disiplin disekolah, yang pada akhirnya akan meningkatkan mutu sekolah.

\section{METODE PENELITIAN}

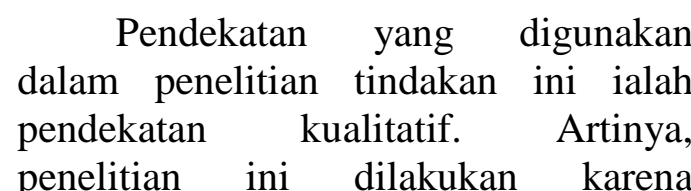
ditemukan permasalahan rendahnya tingkat kedisiplinan guru dalam kehadiran dikelas. Permasalahan ini ditindaklanjuti dengan cara menerapkan sebuah model pembinaan kepada guru berupa keteladanan (contoh) yang dilakukan oleh kepala sekolah, kegiatan tersebut diamati kemudian dianalisis dan direfleksi. Hasil revisi kemudian diterapkan kembali pada siklus-siklus berikutnya.

Penelitian ini adalah penelitian tindakan model Stephen Kemmis dan Mc. Taggart (1998) yang diadopsi oleh Suranto $(2000 ; 49)$ yang kemudian diadaptasikan dalam penelitian ini. Model ini menggunakan sistem spiral refleksi diri yang dimulai dari rencana, tindakan, pengamatan, refleksi, dan perencanaan kembali yang merupakan dasar untuk suatu ancang ancang pemecahan masalah. Seperti yang diungkapkan oleh Mills $(200 ; 17)$ "Stephen Kemmis has created a well known representation of the action research spiral ...". Peneliti menggunakan model ini karena dianggap paling praktis dan aktual.

Pada dasarnya Kegiatan penelitian tindakan sekolah ini, terdiri atas beberapa tahap, atau siklus uji coba lapangan. Setiap siklus terdiri-dari :

a. Perencanaan (Plan)

Membuat perencanaan tindakan untuk melakukan perbaikan disiplin kerja Guru. Tahap - tahap yang disiapkan dalam perencanaan antara lain :

1. Manetapkan jadwal penelitian

2. Mengkaji tata tertib pegawai yang sudah dibuat disekolah

3. Menyusun perencanaan tindakan, agar terjadi peningkatan disiplin kerja.

4. Menyusun lembar pengamatan yaitu lembar pengamatan siswa terhadap guru.

b. Pelaksanaan

Tindakan yang utama dalam penelitian ini adalah keteladan pemimpin untuk meningkatkan disiplin kerja pegawai.

c. Pengamatan

Pengamatan berfungsi untuk mengumpulkan data sekunder selama penelitian berlangsung. Instrumen yang digunakan adalah :

1. Buku jurnal Kelas yang diperoleh dari guru pada saat kegiatan pembelajaran.

2. Daftar hadir atau absensi pegawai yang diperoleh dari guru pada saat memasuki sekolah.

3. Instrumen pengamatan siswa terhadap guru yang diperoleh dari siswa pada saat siswa menilai kedisiplinan guru dalam pembelajaran.

\section{d. Refleksi}

Merupakan upaya mengkaji apa yang terjadi, telah dihasilkan atau tidak atau belum selesai pada siklus yang berjalan. Kegiatan refleksi meliputi kegiatan: (1) analisis, sistesis, (3) interpretasi , dan (4) eksplanasi yang diperoleh pada setiap hari dan pada siklus.

Langkah-langkah penelitian tindakan sekolah dapat digambarkan seperti gambar dibawah ini:

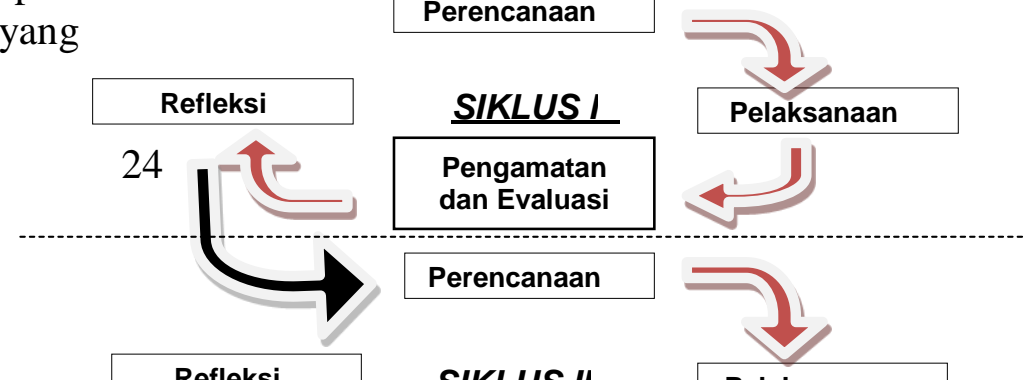




\section{Gambar 1. Langkah-langkah Penelitian Tindakan Sekolah}

Teknik pengumpulan data dari penelitian tindakan sekolah ini adalah melalui data kualitatif yang diperoleh dari observasi, pengamatan, maupun wawancara. Teknik pengumpulan data yang digunakan, menggunakan teknik sebagai berikut:

1. Data diperoleh dari buku jurnal Kelas / pembelajaran guru setiap masuk kelas, yang dipegang oleh siswa dan diisi oleh guru. Dengan mengisi buku jurnal kelas, menerangkan guru sampai dimana bahan yang diajarkan ke siswa, menggambarkan keadaan siswa, sampai dimana kegiatan pembelajaran berlangsung, tanda tangan guru yang mengajar, nama guru mengajar atau tidak mengajar, mata pelajaran yang terjadi saat itu, sering dinamakan sekenario situasi pembelajaran.

2. Daftar hadir guru dan pegawai, daftar hadir guru diperoleh dari absensi guru diwaktu memasuki sekolah dan setelah jam belajar selesai atau pada saat pulang.

3. Instrumen pengamatan siswa terhadap kedisiplinan guru-guru dalam pembelajaran. Instrumen pengamatan siswa digunakan untuk menyampaikan informasi tentang kedisiplinan guru dalam kegiatan pembelajaran dikelas. Instrumen yang digunakan berupa minat dan motivasi model ARCR dari Keller (1987) yang dialihbahasakan oleh Kardi (2002 b), dengan cara melingkari angka dibelakang pernyataan yang telah disediakan, dengan kriteria sangat tidak setuju, tidak setuju, ragu-ragu, setuju, sangat setuju. Instrumen diberikan pada setiap akhir siklus.

Adapun teknik analisis data pada penelitian ini yaitu:

1. Analisis Data Buku Jurnal Kelas.

Analisa data yang digunakan dalam penelitian ini adalah analisa data kualitatif yang bersumber dari data primer maupun empiris. Melalui analisa data ini, dapat diketahui ada tidaknya peningkatan kedisiplinan guru dalam kehadiran dikelas yang merupakan fokus dari penelitian tindakan sekolah ini. Untuk meningkatkan kedisiplinan guru dianalisis dengan statistik deskriptif yaitu dengan menggunakan kedisiplinan guru-guru secara menyeluruh jika mencapai $85 \%$ dinyatakan disiplin dalam bekerja.

Proporsi disiplin kerja guru dapat dihitung dengan cara membagi jumlah guru-guru yang melakukan kehadiran dalam pembelajaran dikelas dengan jumlah guru-guru yang melakukan pembelajaran seluruhnya dikali 100\% (Ibrahim, M. 2000)

\section{Analisis Daftar Hadir Guru}

$$
\text { Sebagai standar tentang }
$$

Peraturan Pemerintah Kabupaten tentang Disiplin Kerja Pegawai No 01 Tahun 2010 Kabupaten Penajam Paser Utara dapat diguanakan untuk menghitung tingkat kedisiplinan guru, dari daftar hadir dapat dihitung dengan cara membagi jumlah guruguru yang mengisi daftar hadir 
dengan seluruh guru yang ada dikalikan $100 \%$.

3. Analisis Instrumen Pengamatan Siswa

Data tentang angket pengamatan siswa yang berupa minat dan motivasi dianalisis dengan menghitung rata-rata tiap kondisi attention (perhatian), relevance (relevansi), Confidence (percaya diri), Santisfaction (kepuasan), criteria pernyataan positif dan negatif. Selanjutnya nilai rata-rata tersebut dikonversikan dengan kategori sebagai berikut:

$$
\begin{aligned}
& 1,00-1,49 \text { tidak baik } \\
& 1,50-2,49 \text { kurang baik } \\
& 2,50-3,49 \text { cukup baik } \\
& 3,50-4,49 \text { baik } \\
& 4,50-5,00 \text { sangat baik }
\end{aligned}
$$$$
\text { (Kardi, S. 2002) }
$$

Selama pengisian instrumen pengamatan siswa terhadap guru dalam kegiatan pembelajaran, diasumsikan seluruh siswa memberi jawaban dengan jujur.

\section{PEMBAHASAN}

\section{Kondisi Awal}

Guru-guru di SMP Negeri 5 Penajam Paser Utara terdiri dari guruguru senior yang mempunyai pengalaman mengajar lebih dari 20 tahun ada 4 orang guru, 15 sampai 20 tahun ada 15 orang guru dan guru-guru muda yang mempunyai pengalaman mengajar dibawah 15 tahun ada sejumlah 14 orang guru. Dari data keadaan guru SMP Negeri 5 Penajam Paser Utara dapat diketahui, jika diratarata pengalaman guru mengajar 13,4 tahun mengajar belum termasuk waktu guru-guru tersebut masih menjadi guru honor dalam bekerja tidak masuk dalam hitungan.

\section{SIKLUS 1}

Siklus Pertama dilakukan sebanyak 2 pekan efektif belajar,bahan perencanaan terdapat pada lampiran.

\section{a. Perencanaan}

Tindakan direncanakan untuk mengatasi permasalahan pada siklus pertama adalah sebagai berikut :

1. Menyusun jadwal piket guru dalam mengatasi kekosongan KBM.

2. Menyusun daftar absensi guru

3. Menyusun Buku jurnal KBM

4. Menyusun Jadwal Pembina Upacara

5. Menyusun jadwal Pembina apel pagi dan siang

6. Menyusun lembar pengamatan ( observasi ) guru dalam KBM.

\section{b. Pelaksanaan Kegiatan}

Pada siklus ini, menyampaikan tujuan dari kedisiplinan guru dan motivasi guru, caranya adalah memberikan contoh-contoh dan prilaku setiap hari, bahwa kita masuk sekolah/KBM tepat waktu dan keluar dari kelas tepat waktu. Contoh lain Pemimpin masuk sekolah tepat pukul 07.00 wita dengan harapan bisa menjadi contoh dan tauladan, sebab waktu belajar masuk pada pukul 07.30 wita jadi ada tenggang waktu 30 menit untuk observasi apa yang harus diperbaiki pada hari itu.

Hal ini bertujuan agar guru guru dapat menemukan kedisiplinan dirinya sendiri memberikan tangung jawab dalam hal lain seorang pemimpin harus menciptakan rasa tanggung jawab guru terhdap tugasnya, menciptakan suasana kerja yang kondusif, membantu guru dalam kesulitan kerja, memberi motivasi guru dalam bekerja.

Pada akhir pekerjaan tindakan, kepala sekolah mengevaluasi kegiatan pelaksanaan tindakan. Kepala sekolah membimbing guru yang mengalami kesulitan dalam bekerja dalam 
pelaksanaan kegiatan ini belum menunjukkan hasil yang memuaskan. Hal ini ditunjukkan dengan adanya kecenderungan kepala sekolah yang selalu datang lebih awal padahal rumah kepala sekolah lebih jauh dari guru-guru yang mengajar di SMP Negeri 5 Penajam dan masih ada beberapa guru yang masuk kelas untuk belajar, guruguru tidak secepatnya masuk ke kelas untuk melaksanakan kegiatan pembelajaran dikarenakan asyik melakukan aktifitas yang lain. Hal ini juga disebabkan tidak adanya koordinasi sistem komando antara kurikulum, guru mata pelajaran, serta BK sehingga ada beberapa kelas yang tidak ada gurunya mengajar dikarenakan guru tersebut sedang pelatihan.

\section{c. Pengamatan ( Observasi )}

Kegiatan pengamatan dilakukan oleh kepala sekolah yang menunjuk salah satu guru dan siswa pada saat KBM. Pengamatan ini difokuskan pada aktivitas guru-guru SMPN 1 Penajam dalam bekerja yang meliputi : guru datang ke sekolah tepat waktu, guru mengikuti apel pagi, guru mengisi daftar hadir, guru masuk kelas tepat waktu, guru mengisi jurnal Kelas, guru membantu siswa dalam KBM, guru keluar kelas setelah jam pelajaran usai. Pengamatan ini berfungsi sebagai masukan bagi kepala sekolah untuk tindakan selanjutnya.

\section{d. Refleksi}

Refleksi dilakukan untuk memberikan informasi /penilaian dari kegiatan guru dalam bekerja. Kegiatan refleksi dilakukan setiap akhir siklus dengan observasi.

\section{SIKLUS 2}

Siklus kedua dilakukan sebanyak dua pekan kegiatan guru dalam proses belajar mengajar

\section{a. Perencanaan}

Tindakan yang direncanakan pada siklus kedua adalah sebagai berikut :

1. Menyusun rencana lembar observasi

2. Menyusun rencana jadwal supervise guru

3. Menyusun jadwal pembinaan pegawai

\section{b. Tindakan}

Pada siklus ke dua perlu dilakukan peningkatan tindakan yang dilakukan oleh kepala sekolah sebagai berikut :

1. Kepala sekolah datang pagi lebih awal yaitu pada pukul 07.00 wita disaat pegawai yang lain belum sampai disekolah

2. Kepala sekolah melakukan pengambilan sampah yang ada dilingkungan sekolah, hal ini dapat dijadikan contoh oleh pegawai yang lain

3. Kepala sekolah menyambut guru disekolah disaat datang ke sekolah (memberi salam, berjabat tangan, menepuk pundak pegawai, dsb)

4. Kepala sekolah menanyakan keadaan (kabar berita), kesehatan keluarga dan pribadi pada saat pegawai datang.

5. Kepala sekolah menanyakan persiapan apa yang sudah dilakukan menjelang KBM.

6. Menanyakan kendala pada saat $\mathrm{KBM}$ (berhalangan hadir pada saat $\mathrm{KBM}$ ) atau permasalahan yang ada.

7. Kepala sekolah memasuki kelas yang kosong apabila guru mata pelajaran tersebut berhalangan hadir.

8. Kepala sekolah memberikan reward pada pegawai apabila pegawainya menyelesaikan tugas dengan benar dan tepat waktu.

9. Kepala sekolah memberikan sanksi pada pegawai apabila pegawainya meninggalkan tugas atau tidak menyelesaikan tugas tanpa alasan yang jelas (diberi tanggung jawab 
tidak diselesaikan) sanksi tersebut berupa pemotongan insentif, honor tidak dibayarkan sebelum pekerjaan selesai.

\section{c. Pengamatan ( observasi )}

Pengamatan dilakukan selama dua pekan efektif kegiatan belajar mengajar dilakukan oleh kepala sekolah dan observer ( observer dapat dilakukan oleh wakil kepala sekolah, wakil kurikulum, BP ) pengamatan pada siklus dua sama dengan yang dilakukan pada siklus pertama yang difokuskan pada aktifitas guru pada saat datang kesekolah sampai pulang sekolah yaitu , guru datang ke sekolah 15 menit sebelum bel masuk jam pelajaran, guru mengikuti apel pagi, guru mengisi daftar hadir, guru masuk kelas sebelum jam pelajaran dimulai, guru mengisi jurnal mengajar, guru membantu siswa dalam kesulitan belajar dikelas, guru keluar kelas pada saat pelajaran selesai. Pengamatan ini sebagai informasi bagi kepala sekolah untuk tindakan tindakan selanjutnya.

\section{d. Refleksi}

Refleksi diakhir siklus bertujuan mengevaluasi secara keseluruhan dampak atau efektifitas dari tindakan yang dilakukan kepala sekolah.

Setelah penelitian dilaksanakan, maka diperoleh hasil sebagai berikut:

\section{Buku Jurnal Kelas}

Berdasarkan hasil analisis buku jurnal mengajar di kelas setiap siklus, bahwa kedisiplinan guru-guru dalam kehadirannya di kelas untuk melaksanakan kegiatan pembelajaran secara bertanggung jawab mencapai $82 \%$ dari 32 guru yang masuk kelas pada dua pekan. Pada siklus dua, setelah pemimpin mengadakan perlakuan disiplin kerja terjadi peningkatan yaitu 95\%, hal ini guru tidak hadir dikelas hanya meninggalkan tugas mandiri dikelas dan guru tersebut ada kegiatan diluar sekolah yang meliputi Bimtek, MGMP, Pelatihan atau sebagai pendamping kegiatan siswa diluar sekolah.

\section{Daftar Hadir Guru}

Dari data absensi daftar hadir guru, pada siklus pertama diperoleh 87,5\% kehadiran guru ke sekolah dari 32 guru. Pada silkus ke dua diperoleh hasil bahwa kedisiplinan guru-guru dalam kehadirannya disekolah untuk mengajar mengalami peningkatan sebesar 96,87\%. Ini dapat dijelaskan bahwa setiap hari, guru yang melakukan pengisian daftar hadir diri diruang satpam sebanyak 32 orang dan guru yang tidak mengisi daftar hadir rata-rata 4 orang guru atau $18 \%$ data menunjukkan selama sepekan dari tanggal 5 sampai 17 september 2017. Hasil analisis uji setiap siklus dapat dilihat pada lampiran. Guru-guru yang tidak hadir ke sekolah dikarenakan ada tiga guru yang mengikuti pelatihan dan dimungkinkan ada beberapa guru tidak mengisi daftar hadir diri karena asyik dengan aktifitas kerja yang lain sehingga terlupakan

\section{Pengamatan Siswa Terhadap Guru-Guru \\ Pendapat siswa terhadap} kedisiplinan guru hadir dalam kegiatan pembelajaran diberikan dengan mengisi angket minat dan motivasi siswa dengan model ARCS yang meliputi attention (perhatian), relevance (keterkaitan), confindence (keyakinan) dan satisfaction (kepuasan). Analisis data angket respon dapat dilihat pada lampiran 3. Ringkasan hasil analisis data respon siswa disajikan pada Tabel 1.

Berdasarkan Tabel 1 tersebut diketahui bahwa siswa menilai kedisiplinan guru-guru SMP Negeri 5 Penajam Paser Utara cukup baik melaui keteladanan pemimpin yang diberikan, hal ini dapat dilihat pada tabel tersebut 
kategori minat siswa terhadap kedisiplinan guru-guru adalah cukup baik dengan skor 3,24. Demikian pula motivasi siswa dengan skor 3,19 menunjukkan kategori cukup baik, ini artinya guru-guru cukup disiplin dalam kehadirannya dikelas melakukan kegiatan pembelajaran.

\section{Tabel 1.}

Rata-rata Kedisiplinan Guru-guru Terhadap Minat dan Motivasi Siswa

\begin{tabular}{|c|c|c|c|c|}
\hline \multirow[t]{2}{*}{ No } & \multirow[t]{2}{*}{ Kondisi } & \multicolumn{2}{|c|}{ Rata-rata } & \multirow{2}{*}{ Kategori } \\
\hline & & Minat & Motivasi & \\
\hline 1 & $\begin{array}{l}\text { Attention } \\
\text { (perhatian), }\end{array}$ & 3,15 & 3,05 & $\begin{array}{l}\text { Cukup } \\
\text { Baik }\end{array}$ \\
\hline 2 & $\begin{array}{l}\text { Relevance } \\
\text { (keterkaitan), }\end{array}$ & 3,32 & 3,25 & $\begin{array}{l}\text { Cukup } \\
\text { Baik }\end{array}$ \\
\hline 3 & $\begin{array}{l}\text { Confindence } \\
\text { (keyakinan) }\end{array}$ & 3,41 & 3,30 & $\begin{array}{l}\text { Cukup } \\
\text { Baik }\end{array}$ \\
\hline 4 & $\begin{array}{l}\text { Satisfaction } \\
\text { (kepuasaan) }\end{array}$ & 3,07 & 3,15 & $\begin{array}{l}\text { Cukup } \\
\text { Baik }\end{array}$ \\
\hline & Rata-rata & 3,24 & 3,19 & $\begin{array}{c}\text { Cukup } \\
\text { Baik }\end{array}$ \\
\hline
\end{tabular}

\section{KESIMPULAN}

1. Keteladanan pemimpin cukup efektif untuk mengajarkan kedisiplinan pegawai, terutama guru-guru. Hal ini dapat dilihat buku jurnal pembelajaran dikelas yang mencapai $95 \%$

2. Kedisiplinan pegawai atau guruguru dapat dilihat dari jumlah kehadiran guru-guru kesekolah, hal ini dapat diketahui dari daftar absensi guru mencapai $96,87 \%$

3. Siswa cukup berminat dan termotivasi untuk belajar jika guruguru meningkatkan disiplin dalam kehadirannya di kelas untuk melakukan kegiatan pembelajaran

\section{DAFTAR PUSTAKA}

Depdikbud. 1999. Bahan Pelatihan Penelitian Tindakan. Jakarta:
Depdikbud, Dirjen Dikdasmen, Dikmenum.

Mills, Geoffrey. 2003. Action Research:

A Guide for the Teacher

Researcher. New Jersey:

Prentice Hall.

Stringer, Ernie. 2004. Action Research in Education. Columbus: Pearson, Menvi Prentice Hall.

PPTK 2011.Penelitian Tindakan Sekolah. Jakarta : PPTK,Badan Pengembangan SDM

Pendidikan, Kemendiknas

Departemen Pendidikan Nasional. (2003). Undang-undang Nomor 20 Tahun 2003 Tentang Sistem Pendidikan Nasional. Jakarta:Depdiknas

Ibrahim, M dan Nur, M. 2000. Pembelajaran Berdasarkan Masalah. Universitas Negeri Surabaya: University Press.

Kardi, S. 2002. Strategi Motivasi Model ARCS. Universitas Negeri Surabaya

Sanjaya, W. (2008). Kurikulum dan Pembelajaran. Teori dan Praktik Pengembangan Kurikulum Tingkat Satuan Pendidikan (KTSP). Jakarta:Kencana Prenada Media Group

Syamsul Hadi, (2009). Kepemimpinan Pembelajaran,

Makalah

Disampaikan pada Sosialisasi Akuntabilitas Kinerja Kepala Sekolah Dalam Inovasi Pembelajaran. Departemen Pendidikan Nasional, Direktorat Jenderal Peningkatan Mutu Pendidik dan Tenaga Kependidikan, Direktorat Tenaga Kependidikan 